Mirjana Čižmešija*

Zrinka Orlovic ${ }^{* * *}$
JEL Classification C53, E32, D12

Izvorni znanstveni rad

\title{
INDEKS POUZDANJA POTROŠAČA KAO NAVJEŠĆUJUĆI INDIKATOR PROMJENA PROMETA U TRGOVINI NA MALO
}

Cilj rada je empirijski ispitati postojanje povezanosti prometa u trgovini na malo i Pokazatelja pouzdanja potrošača na razini Europske unije $i$ na razini euro područja. Pokazatelj pouzdanja potrošača (engl. Consumer Confidence Indicator, CCI) je kompozitni pokazatelj ocjena i očekivanja potrošača u zemljama EU i EA. U istraživanju se ispituje mogućnost predviđanja smjera promjene prometa u trgovini na malo, a ne i intenziteta te promjene. Pri tome se ispituje povezanost predviđenih (po promjenama CCI-a) $i$ ostvarenih promjena prometa u trgovini na malo (na godišnjoj razini) za određeno vrijeme prethođenja. U tu svrhu u analizi je korišten VAR model, Grangerov test uzročnosti, konfuzijska matrica i Hi-kvadrat test nezavisnosti obilježja u tablici kontingence. Uočeno je da promjene CCI-a prethode promjenama prometa u trgovini na malo dva (za EU) i tri (za EA) mjeseca $i$ da su planirane $i$ ostvarene promjene statistički značajno povezane. U oko $80 \%$ slučajeva su promjene za navedeno vrijeme prethođenja (na godišnjoj razini) istosmjerne. Dodatno su izračunani koeficijenti korelacije pomičnog okvira i utvrđena nestabilnost povezanosti među varijablama kroz vrijeme.

Ključne riječi: Pokazatelj pouzdanja potrošača, promet u trgovini na malo, VAR model, Grangerov test uzročnosti, konfuzijska matrica, korelacija pomičnog okvira

* Dr. sc. M. Čižmešija, redovita profesorica, Ekonomski fakultet Sveučilišta u Zagrebu (Email: mcizmesija@efzg.hr).

** Z. Orlović, univ. bacc. oec., studentica sveučilišnog diplomskog studija, Ekonomski fakultet Sveučilišta u Zagrebu (E-mail: orlovic.zrinka1@gmail.com).

Rad je primljen u uredništvo 30.11.2017. godine, a prihvaćen je za objavu 11.01.2018. godine. 


\section{Uvod}

U vrijeme kada su još svježi dojmovi o Velikoj recesiji globalnih razmjera i kada njene posljedice još uvijek osjeća ne mali broj nacionalnih gospodarstva, svijest o negativnim događanjima u makroekonomskom okruženju ponovno aktualizira temu iznalaženja što boljih prethodećih indikatora. Jedan od važnih izvora podataka temeljem kojih se izračunavaju prethodeći indikatori su ankete pouzdanja poduzeća i potrošača, BCS (engl. Business and Consumer Survey).

Iako su ove ankete prisutne u znanstvenoj i stručnoj javnosti već više desetaka godina, i dalje su predmet interesa i izvor vrijednih informacija za praćenje i predviđanje promjena u gospodarstvu, na nacionalnoj, regionalnoj i globalnoj razini. Budući da su istraživanja gotovo u potpunosti usklađena na EU razini, ona su izvor međunarodno usporedivih, visoko frekventnih pokazatelja, čija važnost posebno raste u pred-recesijskom i recesijskom razdoblju. I dalje se preispituju prediktivna svojstva različitih indikatora.

Identifikacija najboljih prethodećih indikatora koji prethode gospodarskim događanjima i koji predviđaju sljedeću fazu ekonomskog ciklusa nesumnjivo je važno pitanje u cilju pravovremene reakcije gospodarstva na negativna događanja poput nedavne recesije (Stundziene et al., 2017.). Odabir prethodećih indikatora nije jedinstven za sve zemlje i sva gospodarstva. Od posebnog interesa je praćenje i predviđanje promjena BDP-a. One se predviđaju temeljem promjena različitih pokazatelja. Financijski pokazatelji, pokazatelji realnog sektora i oni derivirani iz BCS-a pokazuju zadovoljavajuće rezultate. U analizi koju su proveli za europodručje, Girardi et al. (2016.) pokazali su da najveću prediktivnu snagu imaju upravo pokazatelji derivirani iz BCS-a. Njihova prednost u odnosu na ostale indikatore je široka sektorska pokrivenost, visoka frekventnost i uključenost očekivanja kao svojevrsnih izraza neizvjesnosti od strane anketiranih subjekata.

Neka su istraživanja pokazala da su prethodeći indikatori bili u mogućnosti predvidjeti Veliku recesiju u zemljama G7 skupine i to u ranoj fazi, iako, po svojoj prirodi, nisu mogli dati odgovor o „dubini“ dolazeće krize (Astolfi et al., 2016.).

Van Aarle i Moons (2017.) također ističu nezanemarivu ulogu ekonomskog sentimenta i neizvjesnosti u obrazloženju i predviđaju promjena u euro području tijekom financijske krize i Velike recesije. Istraživanje je provedeno u četiri sektora: prerađivačka industrija, trgovina na malo, uslužni sektor i građevinarstvo.

Snažnu povezanost između indikatora potrošačkog sentimenta iz BCS-a i izdataka za osobnu potrošnju, kao i varijabli stambenog tržišta empirijski su potvrdili Kilic i Cankaya (2016.) za američko tržište.

Nedvojbeno je da se u pokazateljima ekonomskog sentimenta (menadžera i potrošača) nalazi veliki potencijal ako se namjerava pratiti i predvidjeti promjene u 
makroekonomskim varijablama. Pri tome treba istaknuti da je zbog prirode BCS-a koji derivira primarno kvalitativne varijable, uputno, temeljem BCS pokazatelja, predviđati smjer, a ne i intenzitet promjene referentne makroekonomske varijable (European Commision, 1997.; European Commision, 2016.).

U skladu s navedenim, postavljena je istraživačka hipoteza rada da su ocjene i očekivanja potrošača iz BCS-a, iako primarno kvalitativne prirode, a potom numerički izražene kroz pokazatelj CCI, reprezentativni prethodeći indikator promjena osobne potrošnje. To znači da se temeljem promjena CCI-a može uspješno predvidjeti smjer promjene obujma prometa u trgovini na malo (kao proxy varijable za osobnu potrošnju) u EU i EA kao cjelinama i to nekoliko mjeseci unaprijed.

Rad je podijeljen u 5 poglavlja, kako slijedi. Nakon uvodnog dijela dan je pregled dosadašnjih istraživanja teme od interesa. U trećem dijelu se nalaze izvori podataka i metode analize, nakon čega slijede rezultati analize s kritičkim osvrt na dobiveno. U zaključku su istaknuti glavni nalazi, ograničenja provedenog i smjernice za novo istraživanje.

\section{Pregled literature}

Iz podataka prikupljenih anketama pouzdanja poduzeća i potrošača (BCS) izračunavaju se različiti numerički pokazatelji. Tako se za trgovinski sektor izračunava Pokazatelj pouzdanja poduzeća u trgovini na malo, RTCI a temeljem rezultata anketa provedenih među potrošačima, između ostalih, izračunava se Pokazatelj pouzdanja potrošača, CCI. Poznato je da RTCI ima svojstvo prethođenja prometu u trgovini na malo, a da je promet u trgovini na malo aproksimacija osobne potrošnje, što znači da se temeljem visokofrekventnih podataka iz BCS-a derivira prethodeći indikator osobne potrošnje. Prediktivna svojstva RTCI-a istraživali su mnogi, na različitim gospodarskim razinama (European Commission,1997.; Čižmešija, 2008. i drugi). Povezanost potrošačkog sentimenta iskazanog kroz CCI i ostalih makroekonomskih varijabli, kao što su primjerice promet u trgovini na malo, odnosno osobna potrošnja, također se empirijski i teorijski istražuje. U nastavku je navedeno nekoliko primjera dosadašnjih istraživanja ove teme, te su i navedeni ključni zaključci.

Easaw et al. (2005.) su u svojem istraživanju istaknuli važnost indikatora pouzdanja potrošača u UK-u prilikom utvrđivanja rasta osobne potrošnje u kratkom roku. Matsusaka i Sbordone (1995.) su na temelju empirijskog istraživanja zaključili da postoji povezanost između potrošačkog sentimenta (mjerenog CCIem) i stope rasta BDP-a. Mourougane i Roma (2002.) analizirali su mogućnost korištenja pokazatelja pouzdanja u prognoziranju rasta BDP-a pojedinih europskih zemalja (Belgija, Njemačka, Francuska, Italija i Nizozemska). Posebno ističu 
mogućnost prognoziranja osobne potrošnje pomoću CCI-a. Ludvingson (2004.) je također potvrdio postojanje povezanosti između indikatora deriviranih iz potrošačkih testova, s jedne strane i osobne potrošnje, s druge strane. On ukazuje da indikatori mogu unaprijed predvidjeti pozitivna i negativna kretanja u ekonomiji te time pomažu nositeljima vlasti prilikom donošenja važnih gospodarskih odluka. Do sličnih zaključaka dolazi Slacalek (2004.). Indikatori potrošačkog testa pružaju dodatne informacije koje pospješuju točnost prognoze, za razliku od varijabli koje su uobičajeno korištene prilikom utvrđivanja razine osobne potrošnje, kao što su nezaposlenost i kamatne stope. Jansen i Nahuis (2004.) su istraživali mogućnost unapređenja predviđanja osobne potrošnje uključivanjem u analizu, osim CCI-a, koji izražava percepcije potrošača, RTCI koji numerički izražava percepcije prodavača robe široke potrošnje. Proveli su empirijsko istraživanje za osam europskih zemalja u periodu od 1985. do 1998. godine. Zaključili su da se uključivanjem u model obaju indikatora povećava njegova „kvaliteta“ prilikom prognoziranja osobne potrošnje u kratkom roku. Postojanje dugoročne povezanosti između pouzdanja potrošača i gospodarskog rasta u odabranim europskim zemljama empirijski su istraživali i Ul Islam i Mumtaz (2016).

Osim na europskoj razini, vrlo slični zaključci proizlaze iz istraživanja provedenih izvan Europe. Tako je na temelju kvartalnih podataka za razdoblje od 1991. do 2007. na području Južne Koreje izračunat Pokazatelj potrošačkog sentimenta (engl. Consumer Sentiment Indicator, CSI) temeljem kojeg su Kim i Goo (2008.) ustanovili njegove snažne prediktivne sposobnosti u predviđanju buduće razine osobne potrošnje. Dees i Brinca (2013.) su temeljem provedene ekonometrijske analize na kvartalnim podacima SAD-a i EA za razdoblje između 1985. i 2010., između ostaloga ustanovili da tijekom geopolitičke napetosti ili financijske krize CCI ima veću snagu predviđanja kretanja osobne potrošnje, nego inače. Istraživanja koja su proveli Olowofeso i Doguwa (2015.) za gospodarstvo Nigerije, također potvrđuju zaključak da CCI ima značajnu ulogu u predviđanju osobne potrošnje. Snažnu povezanost između CCI-a i izdataka za osobnu potrošnju, kao i varijabli stambenog tržišta empirijski su potvrdili Kilic i Cankaya (2016) za američko tržište.

Hrvatska provodi ankete potrošača od 1999. godine, te postoji nekoliko radova koja se bave ovom tematikom na slučaju Hrvatske. Rani radovi koji su se bavili analizom prediktivnih svojstava BCS pokazatelja koristili su jednostavne ekonometrijske metode i modele zbog kratkih vremenskih nizova (Nikić, 2001, Nikić et al., 2002 i dr.). S vremenom su se rezultati potrošačkih testova pokazali kao dobri prediktori kretanja makroekonomskih varijabli, te time njihova upotrebljivost dobiva na važnosti. Čižmešija (2008.) je analizirala podudaranje smjerova kretanja pokazatelja pouzdanja potrošača i BDP-a i empirijski potvrdila da su promjene u oko 66\% slučajeva bile istosmjerne. Čižmešija, Erjavec i Bahovec (2010.) dokazale su da su izračunati pokazatelji na temelju BCS podataka povezani s hrvatskom industrijom i cjelokupnim gospodarstvom Hrvatske. Potrošači i menadžeri, te njihova 
očekivanja izražena kroz pokazatelje izračunate za industriju, usluge i potrošače imaju značajan utjecaj na hrvatsko gospodarstvo i to s pomakom od tri do pet mjeseci. Sorić i Marković (2010.) pokazali su da postoji značajna povezanost između kretanja razine trgovine na malo i CSI-a za Hrvatsku. U radu je stavljen naglasak na ocjenu prediktivnih svojstava CSI-a u predviđanje kretanja osobne potrošnje. Kuzmanović i Sanfey (2012.) zaključuju da CSI ima važnu ulogu prilikom utvrđivanja budućeg kretanja prometa u trgovini na malo, a samim time i na promjene bruto domaćeg proizvoda. Sorić (2012.) proučava, kroz rezultate dobivene testovima potrošača, kako hrvatski potrošači percipiraju inflaciju i kakva kretanja inflacije očekuju. Zaključuje da hrvatski potrošači pokazuju realna očekivanja budućih kretanja cijena. Također, potrošači često pogrešno tumače prijelazne i trajne šokove inflacije čime precjenjuju kretanje inflacije. Čižmešija i Sorić (2013.) pokazali su, na temelju rezultata testova potrošača, da potrošači s obzirom na dob, obrazovanje i prihod drugačije percipiraju porast cijena. Pokazali su da spol nije značajan prilikom prognoziranja kretanja inflacije. Također, potrošači koji su osjetili hiperinflaciju teško mogu imati realna očekivanja vezana uz inflaciju. Čižmešija (2017.) je zaključila na temelju korištenih podataka za EU, EA i Hrvatsku da su očekivanja menadžera i potrošački sentiment prezentirani putem pokazatelja pouzdanja statistički značajno povezani. Ta povezanost je znatno slabija za vrijeme ekonomskih šokova kao što su recesija, izrazito visoka inflacija i slično. Temeljem svega navedenoga, zaključuje se da između pokazatelja izračunanih iz ocjena i očekivanja menadžera i potrošača u anketama pouzdanja poduzeća i potrošača i makroekonomskih varijabli postoji snažna povezanost, te da navedeni pokazatelji imaju svojstvo prethođenja makroekonomskim varijablama više mjeseci unaprijed. Ovo je posebno važno, ako se ima na umu da su pokazatelji pouzdanja poduzeća i potrošača visoko frekventni i dostupni značajno ranije od podataka službene statistike.

\section{Metodologija istraživanja i izvori podataka}

Istraživanje provedeno u ovom radu fokusirano je na agregatne razine EU i EA. Korišteni su mjesečni (sezonski i kalendarski prilagođeni) podaci o prometu u trgovini na malo i CCI-a za EU i EA. Pribavljeni su iz dva izvora. Podaci o prometu u trgovini na malo preuzeti su s internetskih stranica Eurostat-a (Eurostat, 2017.), dok su vrijednosti CCI-a preuzete s internetske stranice Europske komisije (European Commision, 2017.). Analizom su obuhvaćeni mjesečni podaci za razdoblje od svibnja 2005. godine do lipnja 2017. godine. Ovako odabranim vremenskim intervalom uključeno je i razdoblje prije velike gospodarske krize. Time je omogućeno uočavanje karakteristika povezanosti analiziranih varijabli prije, za vrijeme i neposredno nakon gospodarske krize. 
CCI je pokazatelj koji numerički izražava ocjene i očekivanja potrošača vezane uz četiri varijable, odnosno anketna pitanja: financijsku situaciju kućanstva, opću gospodarsku situaciju u zemlji, promjenu broja nezaposlenih i očekivanu štednju, sve kroz narednih dvanaest mjeseci. Pokazatelj je prosjek sezonski prilagođenih ${ }^{1}$ razlika (salda) postotnih udjela „povoljnih“ i „,nepovoljnih“ odgovora anketiranih potrošača na navedena pitanja, s tim da se očekivana promjena broja nezaposlenih primjenjuje s negativnim predznakom. Pitanja u anketnom upitniku su (Čižmešija, 2008.): (Q2) - Što očekujete, kakva će biti financijska situacija vašeg kućanstva u sljedećih dvanaest mjeseci? (++ znatno će se poboljšati, + malo će se poboljšati, = ostati će ista, - malo će se pogoršati, -- znatno će se pogoršati i $N$ ne znam), (Q4) - Što mislite, kakva će biti općenita gospodarska situacija u zemlji u sljedećih dvanaest mjeseci? (++ znatno će se poboljšati, + malo će se poboljšati, = ostati će ista, - malo će se pogoršati, -- znatno će se pogoršati i $N$ ne znam), (Q7) - Što očekujete, kako će se mijenjati broj nezaposlenih u sljedećih dvanaest mjeseci? (Broj će se: ++ dosta povećati, + neznatno povećati, = ostati će isti, - neznatno smanjiti, - - dosta smanjiti i $N$ ne znam) i (Q11) - Koliko je vjerojatno da ćete nešto uštedjeti u sljedećih dvanaest mjeseci? (++ vrlo vjerojatno, + manje vjerojatno, - nije vjerojatno, - - uopće nije vjerojatno, $N$ ne znam).

Uporabom odabranih ekonometrijskih metoda i modela ispitana je povezanost CCI-a i prometa u trgovini na malo. Korištena je VAR metodologija kako bi se utvrdila međuovisnost analiziranih varijabli s vremenskim pomakom. Također je primijenjen Grangerov test uzročnosti. Budući da se u ispitivanju prediktivnog svojstva CCI-a, naglasak stavlja na uspješnost predviđanja smjera, ne i intenziteta promjene, sastavljena je konfuzijska matrica, te je proveden Hi-kvadrat test nezavisnosti obilježja u tablici kontingence. Kako bi se ispitala stabilnost povezanosti između analiziranih varijabli kroz vrijeme, izračunani su koeficijenti korelacije pomičnog okvira (engl. rolling window correlation coefficients).

\section{Rezultati istraživanja}

U skladu s harmoniziranom europskom metodologijom BCS-a, promet $\mathrm{u}$ trgovini na malo uključuje se u analizu kao stope promjene u istoimenim mjesecima (na godišnjoj razini, godišnje stope rasta). Korištene su sljedeće kratice: CCI-EU - Pokazatelj pouzdanja potrošača u EU, CCI-EA - Pokazatelj pouzdanja potrošača u EA, S-RTEU - godišnja stopa rasta obujma prometa u trgovini na malo u EU i S-RTEA- godišnja stopa rasta obujma prometa u trgovini na malo u EA.

\footnotetext{
1 Podaci su desezonirani metodom DAINTIES.
} 
Slika 1 .

CCI I STOPE PROMJENE PROMETA U TRGOVINI NA MALO U EU I EA

a) Europska unija (EU)

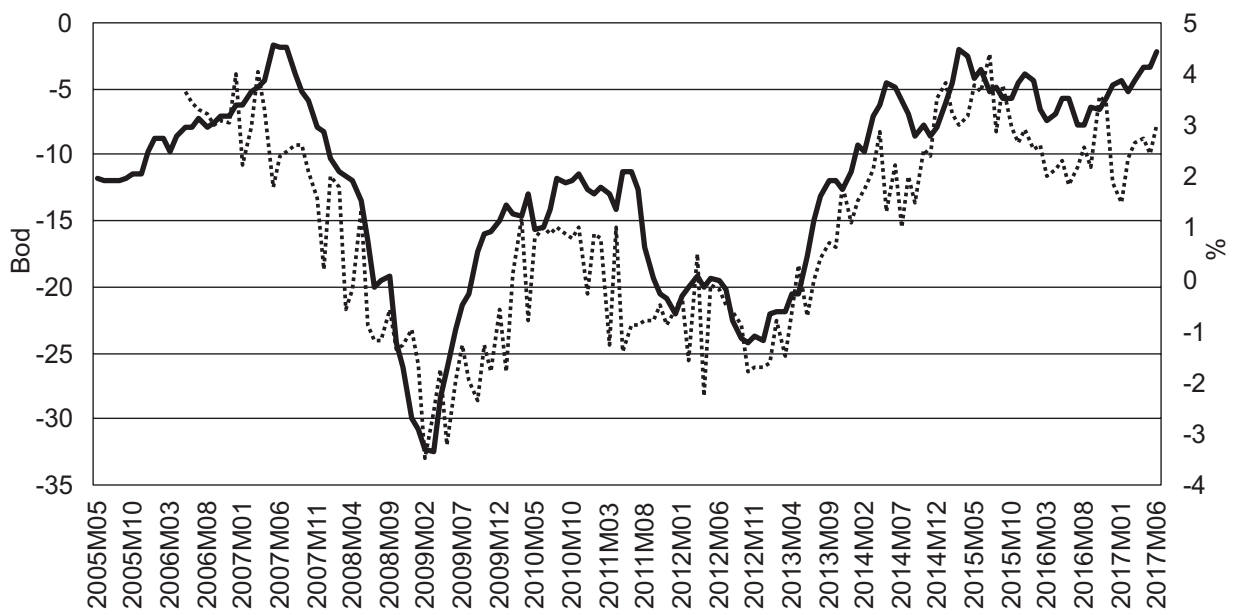

- CCI-EU (LS) …..... S-RTEU (DS)

b) Europodručje (EA)

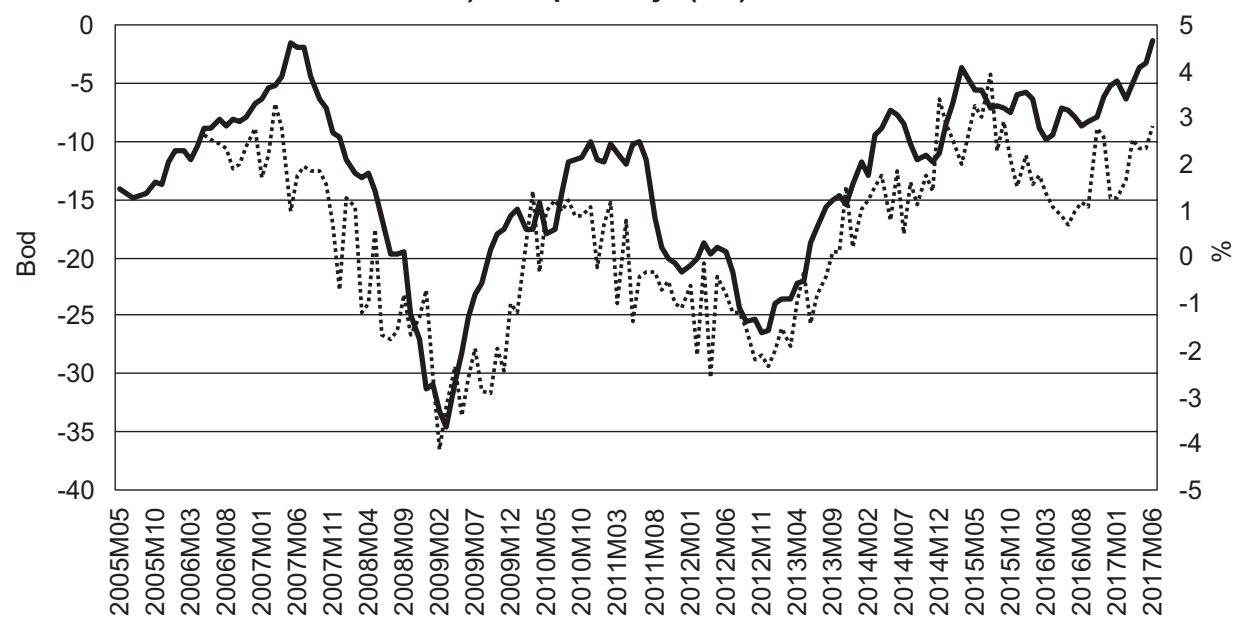

-CCI-EA (LS) ……S-RTEA (DS)

Izvor: Izrada autorica prema podacima objavljenim na: http://ec.europa.eu/eurostat/data/database i https://ec.europa.eu/ 
Na Slici 1. prikazana je dinamika kretanja CCI-a i stopa promjene obujma prometa $u$ trgovini na malo ( $u$ istoimenim mjesecima) na agregatnoj razini EU i na agregatnoj razini EA. Na temelju oba grafička prikaza može se uočiti da obje varijable imaju vrlo sličnu dinamiku kretanja. Varijable su postigle vrlo velike vrijednosti 2007. godine, a nakon toga bilježe značajno smanjenje zbog najave i pojave gospodarske krize. Najmanje vrijednosti postignute su krajem 2008. i početkom 2009. godine. Nakon toga razdoblja vrijednosti varijabli se povećavaju što upućuje na porast povjerenja potrošača i time praćen oporavak trgovinskog sektora. Do 2015. godine obje varijable su znatno fluktuirale. Tijekom 2012. godine ponovno su bile na relativno maloj razini, kada se koristio izraz ,drugo dno krize“. Nakon 2015. godine, vrijednosti CCI pokazatelja i S-RT-a su se stabilizirale i to na relativno velikim razinama. Porast CCI-a je značio porast optimizma potrošača, što je generiralo i porast prometa u trgovini, odnosno porast osobne potrošnje. Na grafičkim prikazima se može uočiti prethođenje CCI-a stopama promjene obujma prometa u trgovini na malo, a u nastavku istraživanja će se ovo svojstvo i numerički ispitati.

U nastavku su dani rezultati analize VAR modela. Cilj analize nije kvantificiranje veze između varijabli u modelu, već analiza uzročnosti i uočavanje mogućnosti korištenja CCI-a u predviđanju promjena prometa u trgovini na malo.

Prvotno je ispitana stacionarnost analiziranih vremenskih nizova. Rezultati ADF testa pokazali su da nizovi nisu stacionarni, odnosno da su svi integrirani reda jedan ${ }^{2}$.

VAR modeli procijenjeni su s diferenciranim nizovima ${ }^{3}$, te je, u skladu s većinom informacijskih kriterija, određen optimalni broj vremenskih pomaka u VAR modelima.

2 Rezultati ADF testa dostupni na zahtjev.

3 Provedena je analiza stabilnosti VAR modela. Procijenjeni modeli su stabilni. Rezultati testa dostupni na zahtjev. 
Tablica 1 .

\section{REZULTATI ODABIRA OPTIMALNOG BROJA POMAKA U VREMENU}

\begin{tabular}{|c|c|c|c|c|c|}
\hline \multicolumn{7}{|c|}{$\begin{array}{l}\text { Za Europsku uniju } \\
\text { D(CCI-EU) i D(S-RTCEU) }\end{array}$} \\
\hline Broj pomaka & LR & FPE & AIC & SC & HQ \\
\hline 0 & NA & 2,380844 & 6,543208 & 6,588461 & 6,561592 \\
\hline 1 & 55,74309 & 1,607310 & 6,150298 & 6,286057 & 6,205449 \\
\hline 2 & $21,41381 *$ & $1,433588^{*}$ & $6,035849^{*}$ & $6,262114 *$ & $6,127769^{*}$ \\
\hline 3 & 4,372974 & 1,472955 & 6,062790 & 6,379561 & 6,191478 \\
\hline 4 & 5,842603 & 1,493568 & 6,076423 & 6,483700 & 6,241878 \\
\hline 5 & 0,755950 & 1,582412 & 6,133792 & 6,631575 & 6,336015 \\
\hline 6 & 5,126317 & 1,612485 & 6,152021 & 6,740310 & 6,391012 \\
\hline \multicolumn{7}{|c|}{ Z(CCI-EA) i D(S-RTCEA) } \\
\hline Broj pomaka & LR & FPE & AIC & SC & HQ \\
\hline 0 & NA & 2,776227 & 6,696846 & 6,742099 & 6,715230 \\
\hline 1 & 47,24309 & 2,009472 & 6,373608 & $6,509367 *$ & 6,428760 \\
\hline 2 & $13,52468^{*}$ & 1,914073 & 6,324902 & 6,551167 & $6,416822^{*}$ \\
\hline 3 & 8,661364 & $1,896445^{*}$ & $6,315501^{*}$ & 6,632272 & 6,444188 \\
\hline 4 & 3,729145 & 1,958342 & 6,347353 & 6,754630 & 6,512808 \\
\hline 5 & 0,894197 & 2,072318 & 6,403509 & 6,901292 & 6,605732 \\
\hline 6 & 6,280644 & 2,090049 & 6,411432 & 6,999721 & 6,650423 \\
\hline
\end{tabular}

Napomena: * označava odabir pomaka po pojedinom kriteriju, uz razinu signifikantnosti 5\%,

LR - Likelihood Ratio (omjer vjerodostojnosti), FPE - Final Prediction Error (pogreška konačne predikcije), AIC - Akaike Information Criterion (Akaike informacijski kriterij), SC - Schwarz Information Criterion (Schwarzov informacijski kriterij), HQ - Hannan-Quinn Information criterion (Hannan-Quinn informacijski kriterij).

Izvor: izračun autorica

Odabran je optimalni broj pomaka u vremenu za diferencirane nizove i to na razini EU dva, a na razini EA tri (mjeseca). Temeljem odabranog broja pomaka proveden je Grangerov test uzročnosti unutar VAR modela. Rezultati testa dani su u tablici 2. 
Tablica 2.

REZULTATI GRANGEROVOG TESTA UZROČNOSTI

\begin{tabular}{|c|c|c|}
\hline \multicolumn{3}{|c|}{ Za Europsku uniju, D(CCI-EU) i D(S-RTCEU), pomak 2} \\
\hline & $\begin{array}{c}\mathrm{H}_{0}: \mathrm{D}(\mathrm{S}-\mathrm{RTCEU}) \text { ne uzrokuje } \\
\mathrm{D}(\mathrm{CCI}-\mathrm{EU}) \text { po Grangeru }\end{array}$ & $\begin{array}{c}\mathrm{H}_{0}: \mathrm{D}(\mathrm{CCI}-\mathrm{EU}) \text { ne uzrokuje } \\
\mathrm{D}(\mathrm{S}-\mathrm{RTCEU}) \text { po Grangeru }\end{array}$ \\
\hline$p$ - vrijednost & 0.1403 & 0.0448 \\
\hline \multicolumn{3}{|c|}{ Za europodručje, D(CCI-EA) i D(S-RTCEA), pomak 3} \\
\hline & $\begin{array}{c}\mathrm{H}_{0}: \mathrm{D}(\mathrm{S}-\mathrm{RTCEA}) \text { ne uzrokuje } \\
\mathrm{D}(\mathrm{CCI}-\mathrm{EA}) \text { po Grangeru }\end{array}$ & $\begin{array}{l}\mathrm{H}_{0}: \mathrm{D}(\mathrm{CCI}-\mathrm{EA}) \text { ne uzrokuje } \mathrm{D}(\mathrm{S}- \\
\text { RTCEA) po Grangeru }\end{array}$ \\
\hline$p$ - vrijednost & 0,3088 & 0,0032 \\
\hline
\end{tabular}

Izvor: izračun autorica

Uz razinu signifikantnosti testa 5\%, zaključuje se da se s prethođenjem (pomakom) od dva mjeseca radi o jednosmjernoj uzročnosti, odnosno da D(CCI-EU) uzrokuje D(S-RTCEU) u Grangerovom smislu, ali ne i obrnuto. Isti zaključak donosi se na razini europodručja, ali za prethođenje (pomak) od tri mjeseca.

Glavni cilj istraživanja je ispitati postojanje povezanosti CCI-a i prometa u trgovini na malo. Naglasak je na predviđanju smjera promjene, a ne i intenziteta. Stoga je u nastavku provedena analiza uspješnosti predviđanja smjera promjene prometa u trgovini na malo. Sastavljene su konfuzijske matrice i provedeni testovi neovisnosti varijabli u tablici kontingence. Praćene su promjene na godišnjoj razini. 
Tablica 3.

KONFUZIJSKA MATRICA: CCI-EU I S-RTEU ZA PRETHOĐENJE OD 2 MJESECA, ZA EU

\begin{tabular}{|c|c|c|c|}
\hline \multirow{2}{*}{ Prognoza } & \multicolumn{2}{|c|}{ Realizacija } & \multirow{2}{*}{ Ukupno } \\
\cline { 2 - 3 } & Povećanje & Smanjenje & 75 \\
\hline \multirow{2}{*}{ Povećanje } & 65 & 10 & $(0,57692)$ \\
\cline { 2 - 3 } & $(0,5)$ & $(0,07692)$ & 55 \\
\hline \multirow{2}{*}{ Smanjenje } & 16 & 39 & $(0,42308)$ \\
\cline { 2 - 3 } & $(0,12308)$ & $(0,3)$ & 130 \\
\hline Ukupno & 81 & 49 & $(1)$ \\
\cline { 2 - 3 } & $(0,62308)$ & $(0,37692)$ & \\
\hline $\mathrm{c}^{2}=44,78839$ & & & \\
\hline
\end{tabular}

Napomena: u dva slučaja jedna od promjena bila je jednaka 0 te su ti slučajevi isključeni iz analize. Frekvencije su izražene apsolutno i (u zagradama) relativno.

Izvor: izrada autorica

Od ukupnog broja mjesečnih opažanja (130) u 50 \% slučajeva došlo je do porasta prometa u trgovini na malo kako je i prognozirano CCI pokazateljem (na godišnjoj razini). Predviđeno i realizirano smanjenje dogodilo se u $30 \%$ slučajeva. Realizirane i predviđene promjene praćene su za prethođenje od 2 mjeseca.

Očekivani smjer promjene prometa u trgovini na malo jednak je smjeru promjene CCI-a (na godišnjoj razini) dva mjeseca unaprijed. Kako bi se provjerilo jesu li planirani i ostvareni smjer promjene prometa u trgovini na malo i CCI-a statistički značajno povezani, proveden je Hi-kvadrat test o nezavisnosti obilježja $\mathrm{u}$ tablici kontingence. Uz razinu signifikantnosti $5 \%$ ne odbacuje se nulta hipoteza, što znači da su planirane i ostvarene promjene prometa u trgovini na malo statistički značajno povezane. Drugim riječima, po CCI-u predviđene i realizirane promjene prometa u trgovini na malo (na godišnjoj razini) u EU međusobno su ovisne i to s prethođenjem od dva mjeseca.

Istovrsna analiza provedena je za EA, s vremenom prethođenja tri mjeseca. 
Tablica 4.

KONFUZIJSKA MATRICA: CCI-EA I S-RTEA ZA PRETHOĐENJE OD 3 MJESECA, ZA EA

\begin{tabular}{|c|c|c|c|}
\hline \multirow{2}{*}{ Prognoza } & \multicolumn{2}{|c|}{ Realizacija } & \multirow{2}{*}{ Ukupno } \\
\cline { 2 - 3 } & Povećanje & Smanjenje & 77 \\
\multirow{2}{*}{ Povećanje } & 65 & 12 & $(0,58779)$ \\
\hline \multirow{2}{*}{ Smanjenje } & $(0,49618)$ & $(0,09160)$ & 54 \\
& 12 & 42 & $(0,41221)$ \\
\hline \multirow{2}{*}{ Ukupno } & $(0,09160)$ & $(0,32061)$ & 131 \\
& $(0,58779)$ & 54 & $(1)$ \\
\hline $\mathrm{c}^{2}=50,67099$ & & $(0,41221)$ & \\
\hline
\end{tabular}

Napomena: U jednom slučaju jedna od promjena bila je jednaka 0 , te je taj slučaj isključen iz analize. Frekvencije su izražene apsolutno i (u zagradama) relativno.

U 49,62\% slučajeva realiziralo se povećanje prometa u trgovini na malo kako je i prognozirano CCI-em tri mjeseca unaprijed, dok se, s druge strane, u 32,06\% slučajeva ostvarilo predviđeno smanjenje prometa u trgovini na malo (na godišnjoj razini). To znači da je u $81,68 \%$ ispravno predviđen smjer promjene prometa $u$ trgovini na malo, temeljem promjene CCI-a tri mjeseca unaprijed. Uz razinu signifikantnosti $5 \%$, a temeljem provedenog Hi-kvadrat testa o nezavisnosti obilježja u tablici kontingence, zaključuje se da su planirane i ostvarene promjene prometa u trgovini na malo u EA statistički značajno povezane. Drugim riječima, po CCI-u predviđene i realizirane promjene prometa u trgovini na malo (na godišnjoj razini) u EA međusobno su ovisne i to s prethođenjem od tri mjeseca.

Stabilnost povezanosti između stopa promjene trgovine na malo i CCI-a za odabrane vremenske pomake ispituje se mjerenjem korelacije pomičnog okvira (engl. rolling-window correlation). Izračunani su 12-člani i 24-člani koeficijenti korelacije pomičnog okvira za pomak (prethođenje) od dva mjeseca (za EU), odnosno od tri mjeseca (za EA). Grafički prikaz koeficijenata korelacije pomičnog okvira dan je na slici 2. 
Slika 2.

12-ČLANI I 24-ČLANI KOEFICIJENTI KORELACIJE POMIČNOG OKVIRA IZMEĐU STOPE PROMJENE PROMETA U TRGOVINI NA MALO I CCI-A ZA EU I EA (POMAK DVA, ODNOSNO TRI MJESECA)

a) Europska unija (EU)
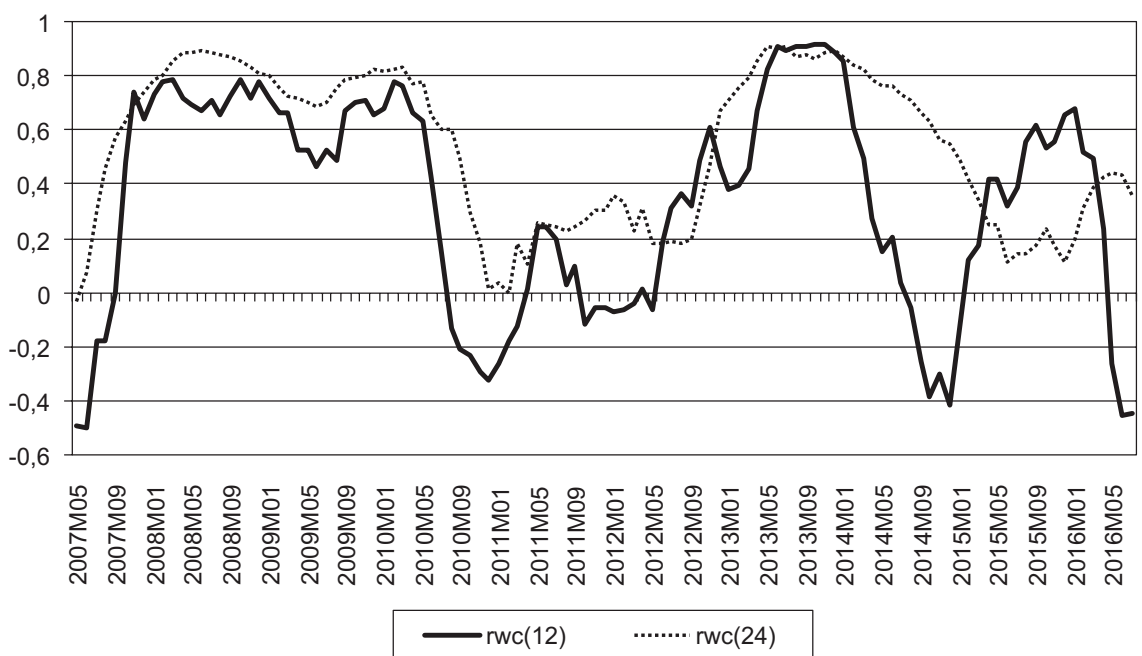

b) Europodručje (EA)

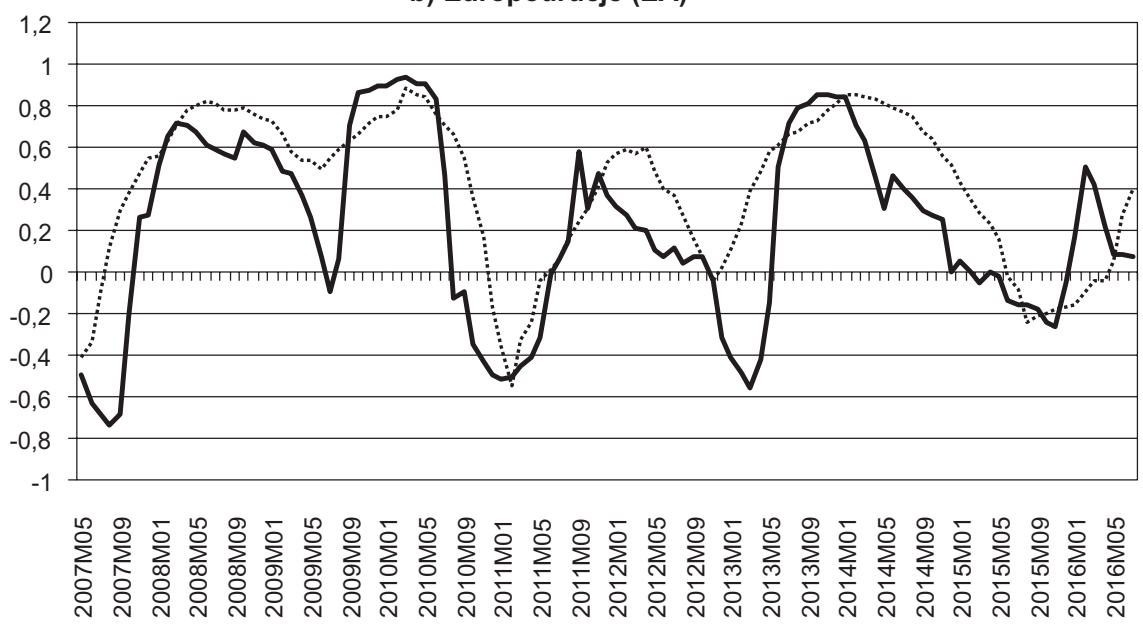

$\longrightarrow \operatorname{rwc}(12) \quad$-........ $\operatorname{rwc}(24)$

Izvor: izrada autorica prema podacima objavljenim na: http://ec.europa.eu/eurostat/data/database i https://ec.europa.eu/ 
Na temelju Slike 2 zaključuje se da povezanost između CCI-a i prometa u trgovini na malo nije stabilna kroz vrijeme. Manje vrijednosti koeficijenata korelacije uočavaju se u 2007. godini. Nakon toga dolazi do povećanja koeficijenata korelacije, odnosno snažnije povezanosti potrošačkog sentimenta mjerenog CCI-em i prometa u trgovini na malo i to u razdoblju između 2008. i 2010. godine. Tu koeficijenti korelacije poprimaju velike vrijednosti (u rasponu od 0,8 do 0,9 ). Također se na slici mogu uočiti male vrijednosti koeficijenata korelacije u razdoblju između 2010. i 2012. godine, te kroz 2015. godinu. Temeljem navedenoga može se zaključiti da je povezanost ocjena i očekivanja potrošača, s jedne strane i prometa u trgovini na malo, s druge strane, nestabilna kroz vrijeme. Ove su varijable snažnije povezane u gospodarski nepovoljnijim razdobljima i obrnuto.

\section{Zaključna razmatranja}

Rezultati empirijskog istraživanja, provedenoga u radu, potvrdili su postavljenu hipotezu. Naime, odabranim ekonometrijskim metodama utvrđeno je da se temeljem promjena CCI-a može uspješno predvidjeti smjer promjene obujma prometa u trgovini na malo (kao proxy varijable za osobnu potrošnju) u EU i EA kao cjelinama i to nekoliko mjeseci unaprijed. S dva mjeseca unaprijed promjene CCI-a u EU u gotovo $80 \%$ slučajeva ispravno najavljuju promjene prometa u trgovini na malo (na godišnjoj razini), dok je taj postotak u EA, za prethođenje od tri mjeseca, $82 \%$.

U radu su prezentirani rezultati istraživanja provedenog za agregatnu razinu EU i EA. Istraživanje prediktivnih svojstva CCI-a i vremena prethođenja osobnoj potrošnji, izraženoj kroz obujam prometa u trgovini na malo po pojedinim zemljama članicama EU zasigurno je izazov za neka nova istraživanja, ujedno i nedostatak provedenoga. Također, iako već postoje neka istraživanja povezanosti potrošačkog sentimenta i prometa u trgovini na malo za Hrvatsku (npr. Sorić i Marković, 2010), vrijedni rezultati mogli bi se postići ispitivanjem povezanosti i mogućeg prethođenja Indeksa očekivanja potrošača (engl. Consumer Expectation Index, CEI) i Indeksa raspoloženja potrošača (engl. Consumer Sentiment Index, CSI) s odabranim makroekonomskim varijablama, između ostalih, s obujmom prometa u trgovini na malo za Hrvatsku ali i po pojedinim zemljama EU i na agregatnim razinama EU i EA. CEI se temelji na očekivanoj financijskoj situaciji kućanstva i očekivanoj općoj gospodarskoj situaciji u zemlji u sljedećih dvanaest mjeseci. CSI obuhvaća ocjenu promjene financijske situacije kućanstva i ocjenu promjene ukupne gospodarske situacije u proteklih dvanaest mjeseci, te ocjenu trenutne mogućnosti kupovine trajnih dobara za kućanstvo. Naime, rezultati 
BCS-a su se s vremenom potvrdili kao vrlo korisni i to na više načina (Čižmešija, 2008): (i) kao pokazatelji općeg gospodarskog stanja i pokazatelji raspoloženja kupaca, (ii) kao podloga za kratkoročne prognoze ekonomskog razvoja i (iii) u kombinaciji sa službenom statistikom, za dugoročne poslovne prognoze, odnosno za određivanje točaka obrata u poslovnim ciklusima. Da bi se BCS rezultati koristili u navedene svrhe, važno je kontinuirano pratiti stupanj njihove kvalitete, a to se čini usporedbom s referentnim vremenskim nizovima službene statistike, odnosno mjerenjem njihove povezanosti i prethođenja.

Napomena: Rad je financirala Hrvatska zaklada za znanost projektom broj IP-11-2013-3858.

\section{Literatura:}

Astolfi, M. Gamba, E., Guidetti, e. i Pionnier, P. A. (2016.). „The use of short-term indicators and survey data for predicting turning points in economic activity: a performance analysis of the OECD system of CLIS during the great recession", OECD Statistics Working Papers, 2016/08 (35 str.), http://dx.doi.org/10.1787/5jlz4gs2pkhfen [pristupano 2. studenoga 2017.].

Čižmešija, M. (2017.). „Povezanost očekivane proizvodnje i pokazatelja pouzdanja potrošača u prerađivačkoj industriji Europske unije“, Ekonomska misao i praksa, (1): $25-40$.

Čižmešija, M. (2008.). Konjunkturni testovi Europske unije i Hrvatske. Zagreb: Binoza press.

Čižmešija, M., Erjavec, N. i Bahovec, V. (2010.). „EU Business and Consumer Survey Indicators and Croatian Economy“, Zagreb International Review of Economics and Business, (13), 2: 15-25.

Čižmešija, M. i Sorić, P. (2013.). „Price sentiment of Croatian consumers: The upward bias of collective memories“, Društvena istraživanja, (22), 1; 1-21.

Dees, S. i Brinca, P. S. (2013.). „Consumer confidence as a predictor of consumption spending: Evidence for the Unites States and the Euro area“, International Economics, 134: $1-14$.

Easaw, J.Z., Garratt, D and Heravi, S. (2005.). „Does consumer sentiment accurately forecast UK household consumption? Are there any comparisons to be made with the US?“, Journal of Macroeconomics, (27), 3: 517-532.

European Commission (2017.). „Economic Databases; Business and Consumer Surveys“, https://ec.europa.eu/info/business-economy-euro/indicators-statistics/economic-databases_en [pristupano 13. siječnja 2017.]. 
European Commission (2016.). „The Joint Harmonised EU Programme of Business and Consumer Surveys, User guide“, http://ec.europa.eu/economy_finance/db_indicators/

surveys/documents/bcs_user_guide_en.pdf [pristupano 13. siječnja 2017.].

European Commission (1997.). The joint harmonized EU programme of Business and Consumer Surveys. Brussel: Directorate-General for Economic and Financial Affairs.

Eurostat, (2017.). Turnover and volume of sales in wholesale and retail trade - monthly data, http://ec.europa.eu/eurostat/data/database [pristupano 30. kolovoza 2017].

Girardi, A., Gayer, C. i Reuter, A. (2016.). „The role of survey data in now casting euro area GDProwth“, Journal of Forecasting, (35), 5: 400-418.

Jansen, W. J. i Nahuis, N. J. (2004.). „Which survey indicators are useful for monitoring consumption? Evidence from European countries", Journal of Forecasting, (23), 2: 89-98.

Kilic, E. i Cankaya, S. (2016.). „Consumer confidence and economic activity: a factor augmented VAR approach“, Applied Economics, (48), 32: 3062-3080.

Kim, S. N. i Goo, Y.W. (2008.). „Is Consumer Sentiment Index useful in Predicting Household Consumption? A directional Analysis with Korean Data“, Journal of the Korean Economy, (9), 2: 205-235.

Kuzmanovic, M. i Sanfey, P. (2012.). „Can Consumer Confidence Data Predict Real Variables? Evidence from Croatia“, Croatian Economic Survey, (15), 1: 5-24.

Ludvigson, S. X. (2004.). „Consumer confidence and consumer spending“, The Journal of Economic Perspectives, (18), 2: 29-50.

Matsusaka, J. G. i Sbordone, A.M. (1995.). „Consumer Confidence and economic flustuations“, Economic Inquiry, (33), 2:296-318.

Mourougane, A. i Roma, M. (2003.). „Can confidence indicators be useful to predict short term real GDP growth?“, Applied Economic Letters, (10), 8: 519-522.

Nikic,G. (2001.). Istraživanje konjunkture u Hrvatskoj. Zagreb: Binoza press.

Nikić, G., Šošić, I. i Čižmešija, M. (2002.). „Business and Investment Surveys in Croatia - A Case Study of an economy in transition", Proceedings of the 26th CIRET Conference in Taipei, 16-19 October 2002.

Olowofeso, O. E. i Douguwa, S. I. (2015.). „Consumer confidence inices and short-term forecasting of consumption for Nigeria“, IFC Bulletins chapters, 39.

Slacalek, J. (2004.). Forecasting consumption, Berlin: German Institute for Economic Research, DIW, Department of Macro Analysis and Forecasting

Sorić, P. (2012.). „Can Croatian Consumers Predict Inflation Dynamics?“, Privredna kretanja i ekonomska politika, (131), 22: 447-456. 
Sorić, P. i Marković, M. (2012.). „Predicting Downturn: Are Tendency Surveys a Good Estimator of Retail Activity in Croatia?“, Ekonomski pregled, (61), 9-10: 559-575.

Stundziene, A., Barkauskas, V. i Giziene, V. (2017.). „The Leading Indicators of the Economic Cycles in Lithuania“, Inzinerine Ekonomika-Engineering Economics, (28), 3: 280-289.

U1 Islam, T. i Mumtaz, M. N. (2016.). „Consumer Confidence Index and Economic Growth: An Empirical Analysis of EU Countries“, Euro Economica, (35), 2: http:// journals.univ-danubius.ro/index.php/euroeconomica/article/view/3541/3685 [pristupano 14. siječnja 2017.]

Van Aarle, B. i Moons, C. (2017.). „Sentiment and uncertainty fluctuations and their effects on the Euro Area business cycle“, Journal of Business Cycle Research, (13), 2: $225-251$.

\title{
CONSUMER CONFIDENCE INDICATOR AS A LEADING INDICATOR OF CHANGES IN RETAIL TRADE TURNOVER
}

\author{
Summary
}

The aim of the paper is to empirically examine the relationship between turnover in retail trade and the Consumer Confidence indicator on the aggregate level of the European Union (EU) and on the aggregate level of Euro zone (EA). The Consumer Confidence Indicator, CCI is a composite indicator of consumers' assessments and expectations in EU and EA. In research, the possibility of forecasting the direction of changes in retail trade turnover is examined, not the intensity of change. The relationship between planned (according to the changes in CCI) and accomplished changes in turnover in retail trade (on a yearly basis) for different time lags is also examined. With this purpose in mind, the VAR model is used in the analysis, along with the Granger causality test, confusion matrix and the Hi-square test of no association in contingency tables. It has been noted that the changes in CCI precede the changes in retail trade turnover with two (for the EU) and three (for EA) months and that their planned and achieved changes are significantly correlated. In around $80 \%$ of cases, the changes for the time lags mentioned above (on a yearly basis) have the same direction. In addition, the rolling window correlation coefficients reveal that the relationship between these two variables is instable through time.

Key words: Consumer Confidence Indicator, Turnover in the retail trade, VAR Model, Granger Causality test, Confusion Matrix, Rolling-Window Correlation 